Short note

\author{
H. M. A. Eltajoury, T. A. Mukassabi, F. M. Altera \& A. M. Elmgasapi
}

\title{
Scolymus maculatus (Asteraceae) new for the Flora of Libya
}

\begin{abstract}
Eltajoury, H. M. A., Mukassabi, T. A., Altera, F. M. \& Elmgasapi, A. M.: Scolymus maculatus (Asteraceae) new for the Flora of Libya. - Fl. Medit. 29: 71-74. 2019. — ISSN: 1120-4052 printed, 2240-4538 online.

Scolymus maculatus L. (Asteraceae) is a species native to the Mediterranean basin found for the first time in Libya. It was discovered growing in a typical silty habitat with other mesophyte plants, very close to the shoreline, about $45 \mathrm{~km}$ east of the city of Benghazi. Records date back to July 2017 and June 2018.

Key words: flora, Compositae, Cyrenaica, North Africa.
\end{abstract}

\section{Introduction}

The Asteraceae is one of the largest plant families in the globe, and consists of more than 30000 species, and 1900 genera (Jafri \& El-Gadi 1983). Scolymus belongs to tribe Cichorieae Lam. \& DC. and includes only three species: S. maculatus L., S. hispanicus L., and S. grandiflorus Desf. (Vazquez 2000). Globally, Scolymus occurs native in South Europe, North Africa and the Mediterranean basin (Vazquez 2000). Up to now only S. hispanicus and S. grandiflorus are reported from Libya (Greuter 2006). S. hispanicus is considered introduced and was collected from near Al Beyda located at $800 \mathrm{~m}$ above the sea level.

Indeed, the flora of Libya is not yet completely known and a number of new plant records are published each year (e.g. Mahklouf 2016).

\section{Materials and Methods}

Plant specimens were first collected from Elmabni area (32 $26^{\prime} 07.26^{\prime \prime} \mathrm{N}, 20^{\circ} 26^{\prime}$ 51.39" E, $2 \mathrm{~m}$ a.s.1.); forty-five km east of Benghazi, $600 \mathrm{~m}$ away from the left side of the main road towards east (Fig. 1a). This species was found during a vegetation analysis project in May 2017 and June 2018. The collected samples were first checked according to the Flora of Libya (Jafri \& El-Gadi 1983). Moreover, further taxonomic investigations were done in the Cyrenaica Herbarium (CHUG) based on Flora of Egypt (Tackholm 1974; Boulos 2002) and Flora of Turkey (Davis \& al. 1975). Plant 
specimens were deposited in the Cyrenaica Herbarium (CHUG), Department of Botany, Faculty of Sciences, University of Benghazi.

\section{Results}

\section{Collection and Taxonomy}

The main differences between the three species of Scolymus are described by Vázquez (2000), since $S$. maculatus is an annual herb with more than five involucral leaves per capitula, capitula terminal and achenes without pappus (Fig. 1b). Whereas, the two other species $S$. hispanicus and $S$. grandifloras that are annual, biennial or perennial herbs, have three or less involuclar leaves per capitulum, capitula terminal or axillary and achenes with pappus. The population sampled belongs without any doubt to $S$. maculatus.

$S$. maculatus was found in relatively a large population, which covers an area of about eight hectares (Fig. 1c) and was obvious that the occurrence of this species dates back to at least 3-4 years or more. We belive that this spceis in Libya can be considered as an alien naturalized of recent introduction. Ten random quadrats of four $\mathrm{m}^{2}$ were made within the concerned area to assess the density and frequency of $S$. maculatus. The individuals were found in $70 \%$ of quadrats made, with a density of 1.2 individ$\mathrm{ual} / \mathrm{m}^{2}$. This species dominates the whole area in association with: Calendula arvensis (Vaill.) L., Lamarckia aurea (L.) Moench, Matricaria aurea (Loefl.) Sch. Bip., Malva parviflora L., Nicotiana glauca Graham, Paronychia arabica (L.) DC. and Suaeda aegyptiaca (Hasselq.) Zohary. Some other species were found scattered within the site such as: Diplotaxis muralis (L.) DC., Emex spinosa (L.) Campd., Plantago coronopus L., Silybum marianum (L.) Gaertn. and Vulpia bromoides (L.) Gray.

\section{General distribution}

Scolymus maculatus is a species native to all countries of the Mediterranean including N. Africa, S. Europe, Crimea, S. Russia and Transcaucasia (Greuter 2006; African Plant Database 2012). The occurrence in Libya was expected since this species was known from all the neighbouring territories (Boulos 2002 ; Le-Floc'h \& al. 2010; Bartolucci \& al. 2018).

\section{Site and climate description}

It was discovered growing in a typical silty habitat in the field among other mesophyte plants and about $130 \mathrm{~m}$ south of halophyte communities, $2500 \mathrm{~m}$ south of the shoreline and $45 \mathrm{~km}$ east of the city of Benghazi. The climate in this area is primarily Mediterranean, very dry summers (June-August) and relatively wet winters (November-April). The highest mean monthly rainfall do not exceed $65 \mathrm{~mm}$ and usually in December and January. The mean annual rainfall within the last two decades is around $300 \mathrm{~mm}$ although very spatially erratic. The mean maximum monthly temperature reaches $41{ }^{\circ} \mathrm{C}$ in June and decreases to $21{ }^{\circ} \mathrm{C}$ in January. The lowest mean minimum monthly temperature is recorded in January and December at $6{ }^{\circ} \mathrm{C}$ and $7{ }^{\circ} \mathrm{C}$, respectively (Mukassabi \& al. 2017). 

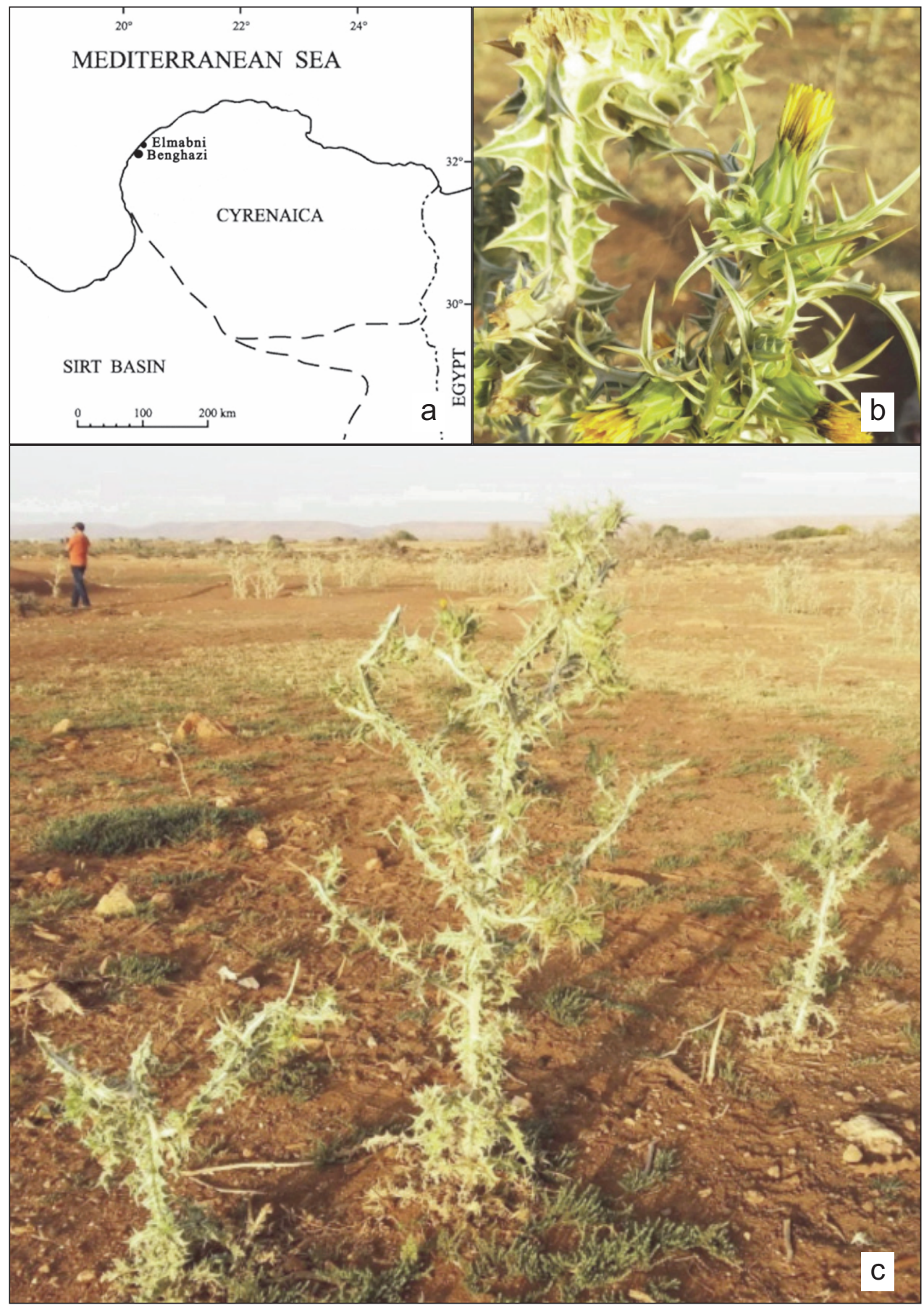

Fig. 1. a) The location of the new record of Scolymus maculatus; b) detail of stem and inflorescence; c) the population covers an area of about eight hectares (Photos by T. Mukassabi). 


\section{References}

African Plant Database. 2012-: (version 3.4.0) Conservatoire et Jardin botaniques de la Ville de Genève and South African National Biodiversity Institute, Pretoria http://www.ville-ge.ch/musinfo/bd/cjb/africa/recherche.php [Last accessed 22 Mar 2019].

Bartolucci, F., Peruzzi, L., Galasso, G., Albano, A., Alessandrini, A., Ardenghi, N. G. M., Astuti, G., Bacchetta, G., Ballelli, S., Banfi, E., Barberis, G., Bernardo, L., Bouvet, D., Bovio, M., Cecchi, L., Di Pietro, R., Domina, G., Fascetti, S., Fenu, G., Festi, F., Foggi, B., Gallo, L., Gubellini, L., Gottschlich, G., Guiggi, A., Iamonico, D., Iberite, M., Jiménez-Mejías, P., Lattanzi, E., Marchetti, D., Martinetto, E., Masin, R. R., Medagli P., Passalacqua, N. G., Peccenini, S., Pennesi, R., Pierini, B., Poldini, L., Prosser, F., Raimondo, F. M., Roma-Marzio, F., Rosati, L., Santangelo, A., Scoppola, A., Scortegagna, S., Selvaggi, A., Selvi, F., Soldano, A., Stinca, A., Wagensommer, R. P., Wilhalm, T. \& Conti, F. 2018: An updated checklist of the vascular flora native to Italy. - Pl. Biosyst. 152(2): 179-303. https://doi.org/10.1080/11263504.2017.1419996

Boulos, L. 2002: Flora of Egypt, 3. - Cairo.

Davis, P. H. 1975: Flora of Turkey and the East Aegean Islands, 5. - Edinburgh.

Greuter, W. (2006-): Compositae (pro parte majore). - in: Greuter, W. \& Raab-Straube, E. von (eds): Compositae. Euro+Med Plantbase - the information resource for Euro-Mediterranean plant diversity. http://ww2.bgbm.org/EuroPlusMed/ [Last accessed 08.10.2018].

Jafri, S. M. H. \& El-Gadi, A. (eds) 1983: Flora of Libya, 107. - Tripoli.

Le-Floc'h, É., Boulos, L. \& Véla, E. 2010: Catalogue synonymique commenté de la flore de Tunisie. - Tunis.

Mahklouf, M. H. 2016: Flora of Solanum rostratum Dunal. (Family-Solanaceae) in Libya: a new record. - Int. J. Mod. Bot. 6: 1-5.

Mukassabi, T. A., Thomas, P. A. \& Elmogasapi, A. 2017: Medicinal Plants in Cyrenaica, Libya: existance and extinction. - Biol. Div. Conserv. 10: 183-192.

Täckholm, V. 1974: Students Flora of Egypt. - Cairo.

Vázquez, F. M. 2000: The Genus Scolymus Tourn. ex L. (Asteraceae): taxonomy and distribution. Anales Jard. Bot. Madrid 58: 83-100. https://doi.org/10.3989/ajbm.2000.v58.i1.139

Address of the authors:

Hussin M. A. Eltajoury, Tarek A. Mukassabi, Fatma M. Altera \& Abdussalam M. Elmgasapi,

Department of Botany, Faculty of Sciences, University of Benghazi. - Benghazi, Libya. E-mail: tarek.mukassabi@uob.edu.ly 